\title{
Effect of fast vs. moderate growth rate related to nutrient intake on developmental orthopaedic disease in the horse
}

\author{
Michaël DonABÉDIAN ${ }^{\mathrm{a}, \mathrm{b} *}$, Géraldine FLEURANCE ${ }^{\mathrm{c} * *}$, \\ Giovanni PERONA $^{\mathrm{d}}$, Céline ROBERT ${ }^{\mathrm{e}}$, Olivier LEPAGE ${ }^{\mathrm{f}}$, \\ Catherine TRILlaUd-GEYL ${ }^{\mathrm{c}}$, Stéphanie LEGER $^{\mathrm{g}}$, Anne RICARD ${ }^{\mathrm{h}}$, \\ Domenico BERGERO $^{\mathrm{d}}$, William MARTIN-ROSSET ${ }^{\mathrm{a} * * *}$
}

\author{
${ }^{a}$ Department of Animal Sciences, INRA, 63122 Saint-Genès-Champanelle France \\ ${ }^{b}$ Department of Human Nutrition and Food Safety, INRA, 63122 Saint-Genès-Champanelle, France \\ ${ }^{\mathrm{c}}$ Haras Nationaux, Experimental Stud, 19370 Chamberet, France \\ d Veterinary Faculty, Torino University, 10195 Grugliasco, Italy \\ e National Veterinary School of Alfort, 94704 Maisons Alfort, France \\ ${ }^{\mathrm{f}}$ National Veterinary School of Lyon, 69280 Marcy l'Étoile, France \\ ${ }^{g}$ Department of Mathematics, Blaise Pascal University, 63000 Clermont-Ferrand, France \\ ${ }^{\mathrm{h}}$ Department of Animal Genetics, INRA, 31326 Castanet-Tolosan, France
}

(Received 31 January 2005 - Accepted 28 March 2006)

\begin{abstract}
Osteochondrosis and other developmental orthopaedic diseases (DOD) constitute major problems in the horse industry. High food allowances and fast growth might be contributory factors. The aim of this experiment was to test the effect of high balanced nutrient allowances and associated fast growth, on the prevalence of several DOD. This study was carried out from birth to one year of age. Foals of a high feeding group (HL, $\mathrm{n}=20$ ) were fed 130\% (0 to 2 months) and $150 \%$ (2 to 12 months) of the moderate level group (ML, $\mathrm{n}=19,100 \%$ of INRA recommendations). All foals were radiographed at 5.5 and 11 months, and 8 foals from each group were necropsied at 12 months of age for gross inspection of joints. Body weight, height at withers and cannon width were higher at 12 months in the HL group $(+88.4 \mathrm{~kg},+4.6 \mathrm{~cm}$, and $+2.1 \mathrm{~mm}$ respectively). The gains in body weight were 1254 and 873 g per day in the HL and ML respectively during the 0-6 month period, and 668 and $528 \mathrm{~g}$ per day in the HL and ML respectively during the 7-12 months period. The occurrence and severity of limb DOD were not statistically different in the HL and ML groups. Fast growth was positively correlated to the occurrence of some DOD lesions, but the body weight was more weakly correlated to the prevalence of DOD than cannon width or height at withers.

\footnotetext{
* Present address: Vétoquinol S.A., Research and Development Division, BP 189, 70204 Lure, France.

** Present address: INRA, Department of Animal Sciences, 63122 Saint-Genès-Champanelle, France.

*** Corresponding author: wrosset@clermont.inra.fr
} 
The power of correlation varied for different types or localisations of lesion. In conclusion, high balanced feeding level was not a sufficient factor in our study, but fast development was a factor of risk for DOD. The lower correlations obtained with body weight do not support the theory that biomechanical limb loading due to increased bodyweight alone increases risk for osteochondrosis. High endomembranous or endochondral ossification rate would be more critical in causing DOD.

\section{horse / nutrition / growth / development / osteochondrosis}

Résumé - Effet d'une vitesse de croissance rapide vs. modérée liée au niveau d'apports nutritionnels sur les affections ostéoarticulaires juvéniles chez le cheval. L'ostéochondrose et d'autres affections ostéoarticulaires juvéniles (AOAJ) constituent un problème majeur pour la filière équine. Des apports nutritionnels accrus et une croissance rapide pourraient induire des AOAJ. Cette étude visait à tester l'effet d'apports nutritionnels élevés mais équilibrés, et de la croissance associée, sur la prévalence de différentes AOAJ. L'étude a porté sur la première année post-natale. Les poulains du niveau haut $(\mathrm{NH}, \mathrm{n}=20)$ ont reçu $130 \%$ (0 à 2 mois) et $150 \%$ (2 à 12 mois) des apports du niveau modéré ( $\mathrm{NM}, \mathrm{n}=19,100 \%$ des recommandations INRA). Tous les poulains ont été radiographiés à 5,5 et 11 mois, et 8 poulains de chaque groupe ont été autopsiés à 12 mois. Poids vif, hauteur au garrot et largeur du canon ont été supérieurs à 12 mois dans le $\mathrm{NH}(+88,4 \mathrm{~kg}$, $+4,6 \mathrm{~cm}$, et $+2,1 \mathrm{~mm}$ respectivement). Le gain de poids vif a été de 1254 et $873 \mathrm{~g}$ par jour pour le $\mathrm{NH}$ et $\mathrm{NM}$ respectivement entre 0 et 6 mois, et 668 et $528 \mathrm{~g}$ par jour pour le $\mathrm{NH}$ et le NM respectivement entre 7 et 12 mois. La présence et la gravité des AOAJ des membres n'ont pas été statistiquement différentes dans les deux groupes. Une croissance rapide a été associée à la présence de certaines AOAJ, mais le poids vif a été moins fortement corrélé à la prévalence des AOAJ que la largeur du canon ou la hauteur au garrot. La puissance des corrélations dépendait de la localisation des lésions. En conclusion, des apports nutritionnels élevés et équilibrés n'ont pas suffi à induire des AOAJ, alors que le format et/ou la croissance ont été des facteurs de risque. L'hypothèse du seul effet mécanique lié à la surcharge pondérale pour justifier l'apparition des AOAJ n'est pas vérifiée par cette étude. En revanche, une intense ossification intramembraneuse ou endochondrale induite pourrait constituer un facteur déterminant de l'apparition des AOAJ.

cheval / nutrition / croissance / développement / ostéochondrose

\section{INTRODUCTION}

Osteochondrosis (OC) has been extensively reported in humans, birds and many mammalian species including horses, pigs and cattle [25]. It results from a disturbance of the endochondral ossification process in the articular-epiphyseal growth cartilage complex. In horses, this condition is a component of the developmental orthopaedic disease (DOD) entity, with other non articular conditions resulting from dysregulation of the metaphyseal growth plate (e.g. physitis, angular limb deformities) [22]. Due to their high incidence [28], the DOD are responsible for significant loss in the horse industry.

The aetiology of DOD implicates genetics [27], biomechanics [42] and nutritional aspects [20]. Glade and Belling [10] reported that overfeeding of weanlings induces osteochondrosis-like growth cartilage morphology changes. More recently, Savage et al. [34] demonstrated that high energy (but not protein) allowances, dramatically increases OC incidence. These lesions could be mediated by overfeeding induced insulin or/and thyroid hormone postprandial secretion pattern changes [11, 30]. Investigations in trace minerals have been spurred by reports that copper and zinc supplementation could decrease the incidence of DOD [19], and the incidence is increased by severe copper deficiency [2]. But debates continue over the level required to prevent DOD [17]. As in other species, feed allowances level is a key regulator of growth in the horse [3].

Horses are fast growing animals, since Thoroughbred foals attain $46 \%$ of mature 
Table I. Distribution of mares and foals between ML and HL groups (means \pm SEM). Breeds: AA: Anglo Arab; Tb: Thoroughbred; SF: Selle Français.

\begin{tabular}{cccc}
\hline & & ML & HL \\
\hline Mares & Body weight (kg) & $533.7( \pm 14.3)$ & $554.7( \pm 9.9)$ \\
& Age (years) & $8.9( \pm 2.1)$ & $10.1( \pm 2.3)$ \\
& Mid-cannon width $(\mathrm{cm})$ & $4.33( \pm 0.05)$ & $4.44( \pm 0.05)$ \\
& Breed (AA, Tb, SF) & $7,3,9$ & $12,3,5$ \\
\hline Foals & Sex ratio (male/female) & $6 / 13$ & $8 / 12$ \\
& Date of birth & April 28 $( \pm 5)$ & April 27 $( \pm 5)$ \\
\hline
\end{tabular}

body weight and $83 \%$ of mature withers height at 6 months [13]. Growth is thus particularly fast during the period when DOD lesions are generated [4]. Fast growth has been associated with a high incidence and/or severity of osteochondrosis lesions in pigs [31], broilers [29], bulls [8] and dogs [44]. In the horse, the relationship between growth rate and skeletal development abnormalities has been suggested in the literature by Moore and McIlwraith [23], but little experimental data have yet been obtained. Field surveys are of interest because they use large numbers of horses [18, 40]. But they do not give an accurate estimation of the effect of fast growth on DOD, because other potential factors (e.g. feeding or exercise) are not controlled and standardised. Experimentally induced growth rate models are thus required and special attention should be paid to the pre-weaning period since many DOD lesions appear during the first months of life [4]. But all the studies have been carried out using weanlings, and are focussed on the effect of imbalance [34,35] or did not investigate joints [3].

The aim of this experiment was to compare the incidence and the severity of DOD in foals with fast and moderate growth rates, induced by two levels of balanced nutrient intake from birth to one year of age.

\section{MATERIALS AND METHODS}

The experiment was approved by the ethics committee of the National Veterinary School of Lyon, France (agreement number CE-ENVL-03/13).

\subsection{Allocation of animals to feeding groups}

Foals of 43 mares (Anglo-Arab, Thoroughbred and Selle Français breeds) were allocated to a high (HL) or a moderate (ML) feeding level group. The mares of both groups were blocked according to breed, body weight, age and mid-cannon width (Tab. I), before being mated by the same 6 Selle Français breed stallions in each group. Nineteen and 20 mares completed pregnancy in the ML and HL group respectively. Date of birth (Tab. I), body weight, and size of the foals at birth (Tabs. II and III) were not different between the 2 groups.

\subsection{Management and feeding of the mares and their foals}

Except if specified, the nutritional models, nutrient adjustment, requirement and recommendations used were always in 
Table II. Body weight (BW) and height at withers (HW) and corresponding average daily gains $(\mathrm{ADG})( \pm \mathrm{SEM})$ in the high $(\mathrm{HL}, \mathrm{n}=20)$ and moderate $(\mathrm{ML}, \mathrm{n}=19)$ feeding level groups; NS: $P>0.05 ; * *: P<0.01 ; * * *: P<0.001$ (t-test).

\begin{tabular}{|c|c|c|c|c|}
\hline \multirow[b]{2}{*}{ Age (months) } & \multicolumn{2}{|c|}{ BW $(\mathrm{kg})$ and ADGBW (g per day) } & \multicolumn{2}{|c|}{ HW $(\mathrm{cm})$ and ADGHW (mm per day) } \\
\hline & ML & HL & ML & $\mathrm{HL}$ \\
\hline birth & $55.8( \pm 2.6)$ & $53.3( \pm 1.4)^{\mathrm{NS}}$ & $102.0( \pm 1.1)$ & $102.2( \pm 0.6)^{\mathrm{NS}}$ \\
\hline 6 & $214.9( \pm 5.7)$ & $274.0( \pm 4.3) * * *$ & $131.5( \pm 1.0)$ & $136.5( \pm 0.6) * * *$ \\
\hline 12 & $302.3( \pm 7.7)$ & $390.7( \pm 6.3) * * *$ & $144.3( \pm 1.0)$ & $148.9( \pm 0.9) * * *$ \\
\hline 0 to 6 & $873( \pm 29)$ & $1254( \pm 25) * * *$ & $1.58( \pm 0.07)$ & $1.90( \pm 0.07) * *$ \\
\hline 0 to 12 & $685( \pm 22)$ & $937( \pm 16) * * *$ & $1.17( \pm 0.03)$ & $1.30( \pm 0.03) * *$ \\
\hline 7 to $12^{\$}$ & $528( \pm 26)$ & $668( \pm 36) * *$ & $0.73( \pm 0.02)$ & $0.69( \pm 0.05)^{\mathrm{NS}}$ \\
\hline
\end{tabular}

$\$$ Between 6 and 7 months: adaptation to automatic feeder and diet, vaccination and anthelmintic treatment.

Table III. Mid cannon width (CW) and corresponding average daily gains $(\mathrm{ADG})( \pm \mathrm{SEM})$ in the high $(\mathrm{HL}, \mathrm{n}=20)$ and moderate $(\mathrm{ML}, \mathrm{n}=$ 19) feeding level groups; NS: $P>0.05$; ***: $P<0.001$ (t-test).

\begin{tabular}{lcc}
\hline \multicolumn{3}{c}{ CW $(\mathrm{mm})$ and ADGCW $(\mu \mathrm{m}$ per day $)$} \\
\hline $\begin{array}{l}\text { Age } \\
\text { (weeks) }\end{array}$ & ML & HL \\
\hline birth & $30.6( \pm 0.4)$ & $30.2( \pm 0.3)^{\mathrm{NS}}$ \\
30 & $36.7( \pm 0.4)$ & $38.9( \pm 0.3)^{* * *}$ \\
52 & $38.0( \pm 0.5)$ & $40.1( \pm 0.4)^{* * *}$ \\
\hline $0-30$ & $28.6( \pm 1.8)$ & $40.9( \pm 1.3)^{* * *}$ \\
$0-52$ & $20.6( \pm 1.0)$ & $29.1( \pm 0.9)^{* * *}$ \\
$30-52$ & $9.7( \pm 1.1)$ & $13.3( \pm 1.3)^{\mathrm{NS}}$ \\
\hline
\end{tabular}

agreement with the standards for the horse as established by INRA [21].

The pregnant mares were fed individually outdoor according to their requirements for maintenance and pregnancy, with monthly adjustments according to their body condition score (BCS) [16] to homogenise the nutritional conditions of foetus development: they were fed 110 , 120 and $130 \%$ of recommendations when $\mathrm{BCS}>3,3 \geq \mathrm{BCS} \geq 2.75$ and $\mathrm{BCS}<2.75$ respectively.
Following parturition, the brood mares were fed individually according to requirements for body weight (BW), milk yield, and BCS. Brood mares of the ML group were fed 100,110 , or $120 \%$ of recommendations for maintenance when $\mathrm{BCS} \geq 3$, $2<\mathrm{BCS}<3$ or $\mathrm{BCS} \leq 2$ respectively. They were fed $100 \%$ of their requirement for milk yield. Individual milk yield was estimated weekly from the 2nd week after foaling, using the average daily gain (ADG) achieved by the foal the previous week [5]. The milk yield for the following week was estimated postulating that milk yield increases by $1 \mathrm{~kg}$ per day until it reaches the maximum of milk production, which is known to be achieved at 2 months of lactation [7]. But the maximum milk yield used to calculate the requirements in the ML group should not exceed $2.9 \mathrm{~kg}$ per $100 \mathrm{~kg} \mathrm{BW}$ during the 1st month and 2.5 $\mathrm{kg}$ per $100 \mathrm{~kg} \mathrm{BW}$ during the 2nd month to ensure a restriction compared to the $\mathrm{HL}$ group. Brood mares of the HL group were fed $100 \%(B C S>3)$ or $120 \%(B C S \leq 3)$ of recommendations for maintenance. They were fed $120 \%$ of their requirements for milk yield, using the minimum value of $3.0 \mathrm{~kg}$ per $100 \mathrm{~kg} \mathrm{BW}$ during the first 2 months of lactation, and to ensure significantly higher ADG when compared to the 
foals of the ML group. The milk yield was estimated as described for the ML group. The mares were always fed a maize based diet supplemented with a concentrate (including minerals and vitamins). During the first two months of lactation, the brood mares of both groups were kept in large grassless paddocks during the day (10h00 to $16 \mathrm{~h} 00$ ) and in individual boxes in which they were fed for the rest of the time. Nutrient intake of the suckling foals was calculated during the two first postnatal months considering the milk intake estimated from the ADG of the foals [5], and the chemical composition of milk (energy and protein). Mineral intake was estimated using NRC models [24] which predict mineral requirements from ADG.

In early spring, all the brood mares were turned out to pasture until weaning at exactly 56 days of lactation. The mares and foals grazed in rotation the same pasture divided into several blocks. But the mares of the HL group were allocated $25 \%$ more surface, and the foals of the HL group were supplemented with $1.5 \mathrm{~kg}$ DM per foal per day of concentrate using a crib-feeding system to maximise their ADG. This concentrate was especially designed for this experiment to get close to the composition of milk ( $40 \%$ ultrafiltrate of lactoserum, $6.5 \%$ soya oil, $12 \%$ casein, $30 \%$ barley, $10 \%$ wheat fine, $1.5 \%$ vitamins; 1.27 UFC per $\mathrm{kg}$ DM, $203 \mathrm{~g}$ MADC per $\mathrm{kg} \mathrm{DM}$ ). Consumption by all the foals was monitored twice a week during one hour after the distribution of concentrate. Since it was not possible to measure or estimate intakes using models in foals consuming a complex diet (milk, grass and concentrate), nutrient intakes from 2 months of age to weaning were interpolated between those calculated before and after this period using models described by Doreau et al. [5] and Martin-Rosset et al. [21].

The foals were similarly weaned in each group to achieve the closest age at weaning: $169 \pm 12$ days in the HL group and
$171 \pm 10$ days in the ML group. After weaning, the foals were allocated to one of the 4 open pens ( $92 \mathrm{~m}^{2}$ per weanling), which included a building for feeding, shelter from rain, and a resting place on a wood shavings bed. Thus, the foals were given the possibility to achieve a normal and homogenous level of exercise in both groups. The foals were fed individually using an automated feeder (prototype manufactured by Orvalex, 50660 Orval, France) that detected the transducer (SL 9007, Texas Instruments Registration and Identification System, Plano, TX, USA) placed in the neck of each weanling. Dry matter intake was measured daily and nutritive values of the feeds were estimated [21] to calculate individual nutrient intake. The goal for ADG from 6 to 12 months of age was to achieve 750 and $500 \mathrm{~g}$ per day in the HL and ML groups respectively, based on previous experiments carried out with the same breeds and diet $[1,15]$. The requirements for growth and the amount of feed to be provided were individually calculated every 14 days for all the weanlings using: BW measured every 14 days and predicted median BW of the following period of 14 days (i.e. using for the following 14 days the average daily gain fixed), and nutritional models established previously [21]:

UFC per d, $\mathrm{BW}^{0.75}=\mathrm{a}+\mathrm{b} . \mathrm{G}^{1.4}$ (d: day; $\mathrm{a}=0.0602 ; \mathrm{b}=0.0183 ; \mathrm{G}=$ daily gain $(\mathrm{kg}$ per d))

MADC $($ g per $d)=a^{\prime} \cdot B^{0.75}+b^{\prime} \cdot G$ ( $\mathrm{a}^{\prime}=3.5 \mathrm{~g} ; \mathrm{b}^{\prime}=450 \mathrm{~g}$ ).

The complete feed used by both groups was formulated especially by INRA to provide in this experiment a moderate amount of starch $(31 \%$ on average for the HL and ML groups) to prevent excessive fattening. Due to some delay in the adaptation to the automatic feeder (one month), additional concentrate feeds were distributed from 6 to 12 months to the HL group to ensure a high difference of ADG. The diet of weanlings was composed of hay (ML: 49.4\%; HL: 44.0\%), corn (ML: 32.8\%; 
Table IV. Ingredient and nutrient composition of diets fed to the weanlings (6 to 12 months).

\begin{tabular}{ccccc}
\hline & & & ML & HL \\
\hline Chemical composition (per kgDM) & MADC (g) & & 103 & 107 \\
& NDF (g) & & 363 & 355 \\
& ADF (g) & & 179 & 176 \\
& Starch $(\mathrm{g})$ & & 285 & 339 \\
& $\mathrm{UFC}$ & & 0.94 & 1.00 \\
\hline Mineral composition (per kgDM) & $\mathrm{Ca}(\mathrm{g})$ & & 6.3 & 5.5 \\
& $\mathrm{P}(\mathrm{g})$ & & 4.7 & 4.0 \\
& $\mathrm{Zn}(\mathrm{mg})$ & & 55 & 57 \\
& $\mathrm{Cu}(\mathrm{mg})$ & & 0.34 & 0.32 \\
\hline Vitamins (IU) & Vitamin A & & 4000 & 3180 \\
& Vitamin D & & 500 & 424 \\
\hline
\end{tabular}

MADC: horse digestible crude protein; UFC: horse feed unit [15,21].

HL: $28.9 \%$ ), barley (HL: $8.9 \%$ ), soya bean meal (ML: $11.0 \%$; HL: 11.5\%), molasses (ML: $5.0 \%$; HL: $5.4 \%)$ and minerals (1.3\% in both groups). The nutritive values of diets for weanlings are provided in Table IV.

Dry matter content (DM) was determined weekly $\left(24 \mathrm{~h}\right.$ at $80{ }^{\circ} \mathrm{C}$ for concentrates and complete feeds and $48 \mathrm{~h}$ for maize silage or hay) to adjust the intake on DM basis. In addition, feeds were sampled monthly to determine chemical composition: ash (oven $550{ }^{\circ} \mathrm{C}$ ), crude fibre (Weende Method), NDF, ADF, ADL [37], starch (Ewers Method), Ca, Zn, Cu (atomic absorption), inorganic phosphorus (colorimetry). Vitamins A and D contents were drawn from the commercial premix formula included in the concentrate. Energy and protein values of solid feeds were predicted from chemical composition using INRA systems [21]. Milk composition was determined from representative samples of milk collected according to a validated process [5]. Fat was determined by Gerber's method, crude protein, lactose and lactose monohydrate by infrared spectrophotometry on a milko-scan analyser [5], and gross energy by calorimetry in an adiabatic bomb.

\subsection{Assessment and treatment of growth data}

Body weight and height at withers (HW) of the foals were assessed weekly from birth to two months of age. Between two and six months of age, the foals were weighed with an electronic scale at the same period of the day according to pasture management ( $48 \mathrm{~h}$ after every rotation at each pasture cycle), about once a month. The weanlings were weighed every two weeks and on two successive days at $0,2,6$ and 12 months of age. Height at withers was measured monthly using a measuring stick. The cannon width $(\mathrm{CW})$ was assessed with an electronic calliper exactly at mid distance between the intercarpal joint and the distal aspect of the metacarpal condyle, at birth, 4, 14, 30 and 52 weeks.

Individual growth curves were established for BW, HW and CW as a function of age. Then individual adjustments of BW and HW to different models were attempted since Gompertz [43] or Richards [32] models were not adapted for short and early periods (12 postnatal months). Finally a third degree polynomial model appeared to be the best fitting model 
$\left(r^{2}>0.93\right)$. Then the average growth curves were defined for each group.

\subsection{Assessment and treatment of osteoarticular data}

\subsubsection{Radiography}

The 39 horses were sedated and radiographed at 5.5 months ( $170 \pm 22$ days) and 11 months ( $333 \pm 5$ days) of age for detection of osteoarticular lesions. The digits (including the interphalangeal and fetlock joints) of the front and the hind limbs, and hocks and the stifles were examined using a lateromedial view. These joints were chosen because they are known to be frequently affected by DOD [41]. The radiographs were evaluated by three experienced equine veterinarians. Radiographic data were analyzed considering the status (affected or not), and the number of lesions. The incidence was the percentage of affected horses in a group. There is no consensus about classification of OC lesions and DOD [14]. Hence, lesions were pooled using topographical or physiopathological criteria. The following pools were successively considered: (1) all lesions of the limbs, (2) the OC and OC-like lesions [14]: lesions of distal tibia, trochlear ridges of the talus and femur, femoral and metacarpal/tarsal condyles, and plantar eminences of the first phalanx, (3) OC lesions [4]: lesions of distal tibial intermediate ridge, and lateral trochlear ridge of the femur and talus, (4) all lesions of fetlock joints, and (5) all lesions of the proximal tarsus: intermediate ridge of the distal tibia, trochlear ridges of the talus and malleolus.

\subsubsection{Necropsy}

At 12 months of age, eight yearlings from each group were euthanised for gross examination of joints. Based on the 11 month X-ray examination results, the most severely affected subjects from each group were selected to collect more pathologically affected tissues for another study, the goal of which was to determine histological changes associated to gross lesions. The atlanto-occipital, intervertebral cervical and all limb joints, except for the coxofemoral and coffin joints were opened and inspected. Lesions were counted and scored using classifications based on those of van Weeren and Barneveld [38]. Pathological or normal status of suspect gross abnormalities was stated by histological examination referring to established criteria [12]. Data were treated considering the following categories of lesions: all (limb and cervical) lesions, limb lesions, cervical lesions, OC lesions or proximal tarsus lesions.

\subsection{Statistical analysis}

The SAS version 9.1 software (SAS Inst., Inc., Cary, NC) was used. The HW, BW and CW growth curves were compared in both groups using a mixed model for repeated measures, with age as a covariable. Mean daily $\mathrm{HW}, \mathrm{BW}$ and $\mathrm{CW}$ gains over several sub-periods were compared in the ML vs. HL groups with a ttest.

The incidence of DOD established by $\mathrm{X}$-ray examination was compared in both groups using a logistic regression; the number of lesions at X-ray was compared using a t-test $(n=39)$; and the number or total score of lesions found at necropsy were compared in the ML vs. HL group using the Kruskal Wallis test $(n=16)$.

To determine the effects of growth on the osteoarticular status, the growth variables of affected vs. sound horses at Xray examination were compared using a logistic regression. Correlations between growth and the number of lesions at radiography or necropsy data were tested using 
Table V. (a) Daily nutrient intake of the foals before weaning. (b) Daily nutrient intake of the weanlings.

(a) foals defore weaning

\begin{tabular}{|c|c|c|c|c|c|c|c|c|c|}
\hline & & & & & & MADC $(\mathrm{g})$ & UFC & $\mathrm{Ca}(\mathrm{g})$ & $P(g)$ \\
\hline & & & & \multirow[t]{2}{*}{$0-2$ months } & ML & 298 & 3.4 & (42) & (23) \\
\hline & & & & & HL & 379 & 4.4 & (53) & (30) \\
\hline & & & & \multirow[t]{2}{*}{$2-6$ months } & ML & 446 & 3.8 & (31) & (17) \\
\hline & & & & & HL & 701 & 5.7 & (43) & (24) \\
\hline \multicolumn{10}{|c|}{ (b) weanlings } \\
\hline & Intake (kg DM) & MADC $(\mathrm{g})$ & UFC & $\mathrm{Ca}(\mathrm{g})$ & $P(g)$ & $\mathrm{Cu}(\mathrm{mg})$ & $\mathrm{Zn}(\mathrm{mg})$ & Vit A (IU) & Vit D (IU) \\
\hline ML & 4.95 & 510 & 4.7 & 31 & 18 & 69 & 248 & 19800 & 2475 \\
\hline HL & 7.18 & 768 & 7.2 & 43 & 27 & 86 & 401 & 22832 & 3044 \\
\hline
\end{tabular}

MADC: horse digestible crude protein; UFC: horse feed unit [15].

In brackets: mineral intakes predicted using equations of NRC [24].

Pearson and Spearman correlation tests respectively. The significance level used was always $P<0.05$.

\section{RESULTS}

\subsection{Feeding level and growth}

The foals of the HL group were on average fed $130 \%$ (until 2 months of age), and $150 \%$ (between 2 months and weaning, and after weaning) of nutrients of the ML group (Tabs. Va and $\mathrm{Vb}$ ).

Body weight, $\mathrm{HW}$ and $\mathrm{CW}$ were higher in the HL compared to the ML group from 1 month, 3 months and 3.2 months (14 weeks) of age respectively $(P<0.05)$. The discrepancy increased with age and the ADG were higher in the HL group except for CW and HW between 7 and 12 months that were not different between groups (Tabs. II, III). Sixty-seven percent of the final difference between both groups for BW was already achieved at six months of age. The final difference of HW was already met at six months of age.

\subsection{Osteoarticular status}

\subsubsection{General data}

The number of lesions was higher at 5.5 months than at 11 months (paired t-test,
$0.022>P>0.005)$, except for fetlock and proximal tarsus lesions (Fig. 1). Inversely, few new lesions appeared after 5.5 months. Thus, the probability for a foal to be affected by DOD at 11 months was about 9 fold (depending on the category of DOD considered) higher if the foal was already affected at 5.5 months.

No physitis or angular deformity was detected in this study. All the horses presented at least one articular lesion at necropsy. Cervical joints were highly affected (mainly the joint between the third and fourth vertebra), with total scores higher than those for limbs. Limb and cervical scores were, however, highly correlated (Pearson test, $P=0.003, \mathrm{R}=0.69$ ). The more frequently affected joints at necropsy were tibiotarsal joints $(60.4 \%$ of lesions at necropsy), stifle joints and shoulders (13\% each) (Fig. 2).

\subsubsection{Effect of feeding level on DOD}

No statistically significant difference was observed at radiographic examination or necropsy between ML and HL groups for any category of limb lesions. Foals from the HL group had, however, significantly more lesions when considering only 

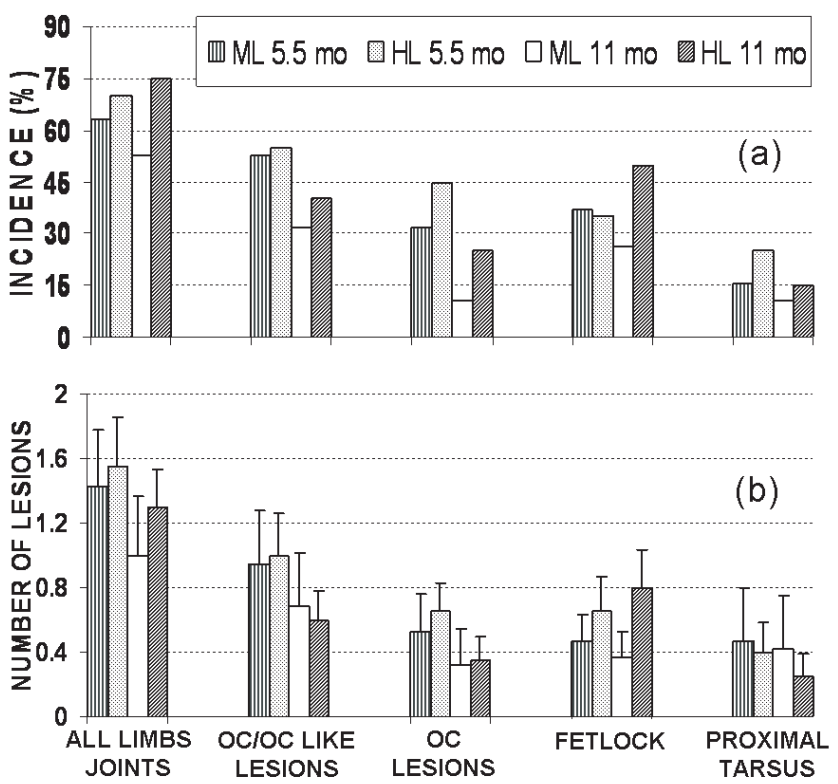

Figure 1. Incidence (a) and number (b) ( \pm SEM) of DOD lesions assessed by X-ray examination at 5.5 and 11 months of age in moderate (ML) and high (HL) feeding groups. ALL LIMB LESIONS: considering all lesions of limbs; OC/OC LIKE LESIONS: considering osteochondrosis and osteochondrosis like lesions [14]; OC LESIONS: considering osteochondrosis lesions [4]; FETLOCK LESIONS: considering all fetlock lesions; PROXIMAL TARSUS: considering lesions of distal tibia and ridges of talus.

cervical joints $(P=0.033)$. When considering all (limb and cervical) joints at necropsy, only a tendency for a higher number and score of lesions was observed ( $P=0.057$ and 0.092 respectively) (Fig. 2).

\subsubsection{Effect of size or growth on DOD}

This effect was investigated pooling the 39 horses, irrespectively of the group they were in. Many correlations between size or growth variables and DOD were significant. The results were, however, slightly dependent on the technique used to detect DOD.

At X-ray examination, the highest correlations between growth and DOD were achieved when considering the incidence (Tab. VI) or number (Tab. VII) of fetlock lesions. Fetlock lesions were highly correlated to the ADG of CW over all tested periods. The statuses with respect to all limb joints, OC/OC like and proximal tarsus lesions at 5.5 months were correlated to $\mathrm{CW}$ or ADGCW. Occurrence of proximal tarsus lesions at 5.5 months was correlated to BW at 2 months at a much smaller odd ratio (Tab. VI). The number of total limb lesions (all limb joints) at 11 months was correlated to BW and HW assessed after weaning (Tab. VII).

At necropsy, the cervical DOD were poorly correlated to size or growth. But all the categories of limb lesions considered at necropsy (all limb, OC, or proximal tarsus lesions) were correlated to size or growth (Tabs. VIII and IX). The ADG were rarely correlated to DOD; the instantaneous HW 

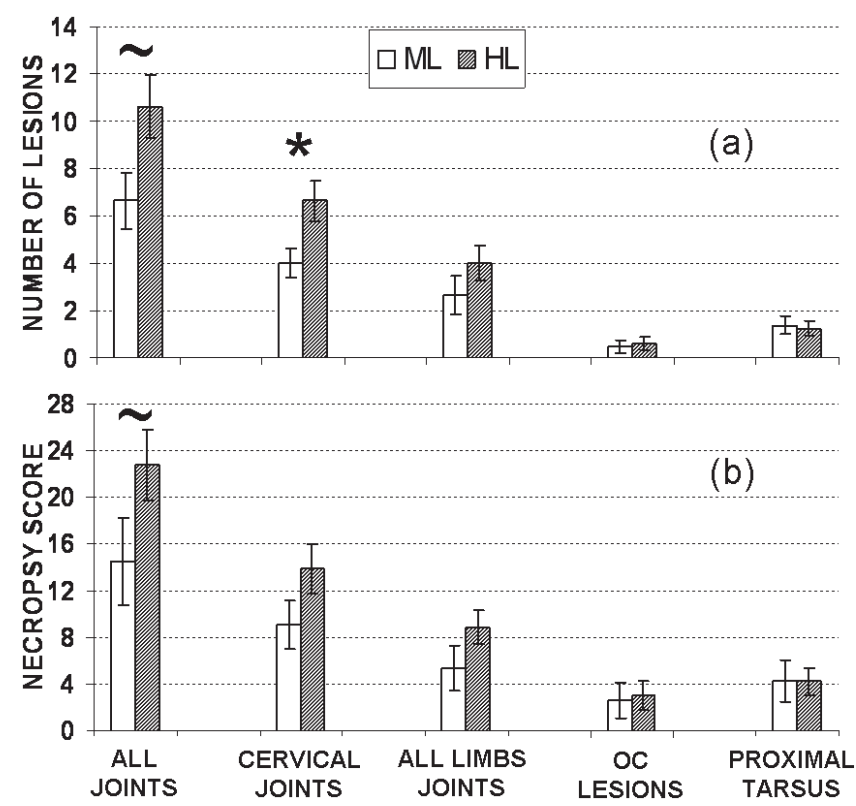

Figure 2. Number (a) and score (b) ( \pm SEM) of DOD lesions assessed by necropsy at 12 months of age in moderate (ML) and high (HL) feeding groups. ALL JOINTS: considering all lesions of limbs and cervical joints; CERVICAL JOINTS: considering only lesions of cervical joints; ALL LIMB JOINTS: considering all lesions of the limbs only; OC LESIONS: considering osteochondrosis lesions of limbs as defined by Dik et al. [4]; PROXIMAL TARSUS: considering lesions of distal tibia and ridges of talus. *: $0.01<P<0.05 ; \sim: 0.05<P<0.10$.

and BW were much more frequently correlated. The HW was by far the size variable most frequently and tightly correlated to DOD, whereas CW and BW were more scarcely correlated to DOD at necropsy. For every type of DOD, HW (and sometimes BW) measured at birth and/or 2 months presented the highest statistical significance.

\section{DISCUSSION}

This experimental study aimed at testing the effect of two feeding induced growth pattern models on the occurrence of DOD. The achievement of two growth models from birth to one year of age was thus a primary step, in order to study the effect of nutrition and associated growth on juvenile osteoarticular diseases. Compared to previous data obtained with the same breeds managed similarly [1,36], the ADG achieved by the foals of the HL group was maximal before weaning (1243 g per day in this experiment vs. $1046 \mathrm{~g}$ per day in previous experiments) and sub-maximal after weaning (618 vs. $703 \mathrm{~g}$ per day in the present and past experiments respectively). The ADG achieved between 6 and 12 months was sub-maximal since maximal ADG was promoted especially before weaning when the DOD lesions are generated [4] and energy concentration of the diet (i.e. starch) was limited to prevent fattening after weaning.

The incidence of DOD considering all radiographic lesions at 5.5 months in this study $(66.7 \%)$ was very close to the 
Table VI. Significant correlations between growth variables and the incidence of DOD lesions assessed by X-ray examination at 5.5 and 11 months.

\begin{tabular}{|c|c|c|c|c|c|}
\hline \multicolumn{2}{|c|}{ DOD from X-ray } & \multicolumn{2}{|c|}{ Growth } & \multicolumn{2}{|c|}{ Significance } \\
\hline Site & Age & Variable & Age/period & $P$-value & Odd ratio \\
\hline \multirow[t]{3}{*}{ All limb joints } & 5.5 & $\mathrm{CW}$ & 14 weeks & 0.022 & 355 \\
\hline & 11 & ADGCW & 0-14 weeks & 0.048 & $>999$ \\
\hline & 11 & ADGCW & 4-14 weeks & 0.033 & $>999$ \\
\hline OC/OC like lesions & 5.5 & $\mathrm{CW}$ & 4 weeks & 0.039 & 116 \\
\hline \multirow[t]{7}{*}{ Fetlock joints } & 5.5 & ADGCW & 0-14 weeks & 0.011 & $>999$ \\
\hline & 5.5 & ADGCW & 4-14 weeks & 0.017 & $>999$ \\
\hline & 5.5 & ADGBW & $0-2$ months & 0.029 & 1.005 \\
\hline & 11 & ADGCW & 0-14 weeks & $<0.001$ & $>999$ \\
\hline & 11 & ADGCW & $0-4$ weeks & 0.004 & $>999$ \\
\hline & 11 & ADGCW & 4-14 weeks & 0.004 & $>999$ \\
\hline & 11 & ADGCW & $0-52$ weeks & 0.016 & $>999$ \\
\hline \multirow[t]{4}{*}{ Proximal tarsus joints } & 5.5 & BW & 2 months & 0.034 & 1.07 \\
\hline & 5.5 & $\mathrm{CW}$ & 4 weeks & 0.015 & 535 \\
\hline & 5.5 & CW & 14 weeks & 0.025 & 453 \\
\hline & 5.5 & ADGCW & 0-14 weeks & 0.036 & $>999$ \\
\hline
\end{tabular}

OC/OC like: osteochondrosis and osteochondrosis like lesions as defined by Hurtig and Pool [14]; HW: height at withers; BW: body weight; CW: cannon width.

incidence observed in a field study $(67.4 \%)$ using the same protocol implemented on 393 foals of the same breeds [33].

The present results were consistent with the study carried out at the Utrecht University with respect to the decrease of OC lesions after weaning as detected radiographically [4]. The general incidence of OC was higher in the previous study (18\% vs. $10.2 \%$ of horses with tibial intermediate ridge OC on 11 month X-ray examination), because foals were purposefully sired by OC positive stallions in that study. Aiming at a high incidence was justified in the Dutch study because a potentially protective effect was tested (exercise). However, when testing a potentially inductive factor, a genetic predisposition could confound any nutritional or growth effect and was thus not indicated in the present study.

Data about cervical joint abnormalities are scarce, since their exploration is only possible by necropsy yet. Our results confirm the high incidence and severity of lesions in these joints as reported by others previously [38]. Cervical lesions possibly follow other pathways than limb joints, since they were positively correlated to feeding level, but not associated to fast growth or large size. The clinical significance of these lesions is yet uncertain.

No statistically significant feeding level effect could be established on limb DOD. Savage et al. [34], who fed weanlings a high energy diet (129\% of control using NRC systems [24]), found a very high incidence of DOD at necropsy (11/12) when compared to the control $(1 / 12)$ or at a high protein diet (1/6). Ott et al. [26] did not detect any effect of energy sources in weanlings fed a high energy level. These observations detect that feed imbalance and high energy intake are stronger DOD inducing factors than a high but balanced feeding 
Table VII. Significant correlations between growth variables and the number of DOD lesions assessed by X-ray examination at 5.5 and 11 months.

\begin{tabular}{llcccccc}
\hline \multicolumn{2}{c}{ DOD from X-ray } & & \multicolumn{2}{c}{ Growth } & & \multicolumn{2}{c}{ Significance } \\
\cline { 1 - 2 } \cline { 6 - 7 } Site & Age & & Variable & Age/period & & $P$-value & R \\
\hline All limb joints & 11 & & HW & 9 months & & 0.016 & 0.38 \\
& 11 & & HW & 6 months & & 0.028 & 0.35 \\
& 11 & & HW & 12 months & & 0.029 & 0.35 \\
& 11 & & BW & 12 months & & 0.040 & 0.33 \\
& 11 & & BW & 9 months & & 0.045 & 0.32 \\
\hline Fetlock joints & 5.5 & & ADGCW & $4-14$ weeks & & 0.002 & 0.47 \\
& 5.5 & & ADGCW & $0-14$ weeks & & 0.006 & 0.52 \\
& 5.5 & & ADGBW & $0-2$ months & & 0.012 & 0.37 \\
& 11 & & ADGCW & $0-14$ weeks & & $<0.001$ & 0.56 \\
& 11 & & ADGCW & $0-30$ weeks & & 0.002 & 0.48 \\
& 11 & & ADGCW & $4-14$ weeks & & 0.003 & 0.46 \\
& 11 & & ADGCW & $0-52$ weeks & & 0.004 & 0.46 \\
& 11 & & BW & 12 months & & 0.018 & 0.38 \\
& 11 & ADGBW & $0-12$ months & & 0.018 & 0.38 \\
& 11 & CW & 52 weeks & & 0.034 & 0.34 \\
& 11 & CW & 30 weeks & & 0.042 & 0.33 \\
\hline
\end{tabular}

HW: height at withers; BW: body weight; CW: cannon width.

Table VIII. Significant correlations between growth variables and the number of DOD lesions assessed by necropsy at 12 months.

\begin{tabular}{lccccc}
\hline DOD & \multicolumn{3}{c}{ Growth } & & \multicolumn{2}{c}{ Significance } \\
\cline { 7 - 8 } \cline { 6 - 7 } Site & Variable & Age/period (months) & & $P$-value & $\mathrm{R}$ \\
\hline All limb joints & HW & Birth & & 0.004 & 0.68 \\
& HW & 2 & & 0.014 & 0.60 \\
& ADGBW & $7-12$ & & 0.020 & 0.57 \\
& BW & Birth & & 0.039 & 0.52 \\
\hline OC lesions & HW & 2 & & 0.004 & 0.67 \\
& HW & Birth & & 0.018 & 0.58 \\
& HW & 6 & & 0.038 & 0.52 \\
\hline Proximal tarsus joints & HW & Birth & & 0.003 & 0.69 \\
& HW & 2 & & 0.006 & 0.66 \\
& BW & Birth & & 0.006 & 0.66 \\
\hline
\end{tabular}

OC: osteochondrosis; HW: height at withers; BW: body weight; CW: cannon width. 
Table IX. Significant correlations between the necropsy severity score of DOD lesions assessed at 12 months.

\begin{tabular}{lccccc}
\hline DOD & \multicolumn{2}{c}{ Growth } & & \multicolumn{2}{c}{ Significance } \\
\cline { 6 - 7 } \cline { 5 - 6 } Site & Variable & Age/period & & $P$-value & C \\
\hline All limb joints & HW & Birth & & 0.009 & 0.63 \\
& HW & 2 months & & 0.009 & 0.62 \\
& HW & 6 months & & 0.037 & 0.52 \\
& HW & 9 months & & 0.039 & 0.52 \\
& BW & Birth & & 0.039 & 0.52 \\
\hline OC lesions & HW & 2 months & & 0.004 & 0.68 \\
& HW & Birth & & 0.037 & 0.52 \\
& CW & 52 weeks & & 0.041 & 0.51 \\
& BW & 2 months & & 0.043 & 0.51 \\
& CW & 14 weeks & & 0.048 & 0.50 \\
\hline Proximal tarsus joints & HW & 2 months & & $<0.001$ & 0.79 \\
& HW & Birth & & 0.003 & 0.69 \\
& BW & 2 months & & 0.016 & 0.59 \\
& HW & 6 months & & 0.018 & 0.58 \\
& CW & 14 weeks & 0.035 & 0.53 \\
\hline
\end{tabular}

OC: osteochondrosis; HW: height at withers; BW: body weight; CW: cannon width.

level using a moderate energy concentration (e.g. starch).

The fast $\mathrm{CW}$ gain (ADG) or large size promoted by the high nutrient allowances were correlated to a higher risk of limb DOD at X-ray or necropsy respectively. The results were always highly joint dependent. The low correlation of DOD to $\mathrm{BW}$ or BW gain in this experiment was consistent with previous results in the horse $[9,18,39]$. Cannon width and HW have been scarcely tested for correlation to DOD in the literature. However, a previous study did not conclude that there was a correlation of HW to OC lesions [39]. The biological significance of the correlation between DOD and CW or HW remains unclear. Positive correlations to $\mathrm{CW}$ gain would suggest that a faster intramembranous ossification rate (responsible for widening of long bones) would be a predisposing factor to DOD. Positive correlation of DOD to HW could indicate that the higher growth cartilage turnover requested to achieve high HW, could be detrimental to the endochondral ossification process (responsible for long bone lengthening) and could induce dyschondroplasia.

The correlations between size or growth parameters and DOD were not consistent when comparing data from necropsy and X-ray examination. The ADG of CW was highly correlated to radiographic fetlock lesions whereas the HW at early time points was the best predictor of limb DOD severity at necropsy. But when considering only the 16 euthanised horses, the number of radiographic lesions and corresponding correlations to growth were very similar to necropsy data (data not shown). The heterogeneity of our results may be explained by the non randomised choice of horses for necropsy ( 8 more affected horses of both groups) and/or the different size of populations. Hence, the results using necropsy data refer to a population 
of affected horses, rather than to a general population.

In this study, all growth parameters were significantly correlated to feeding level. Some growth parameters, but not feeding level, were correlated to the occurrence of DOD. If growth and format were only regulated by feeding level, this outcome would be impossible. The present results highlight that the genetic influences on the regulation of growth contribute to the significant correlation of growth and size to DOD. Growth or size parameters reflect both nutritional and genetic factors. The outcome of the study suggests that there is an association between genetic predispositions for a large size and the occurrence of DOD.

\section{CONCLUSION}

It can be concluded from this study that a high but balanced plane of nutrition (using a moderate energy concentration, thus limited carbohydrate) per se during the first and complete postnatal year does not significantly increase the occurrence and severity of limb DOD. And high BW and HW met at 12 months of age accounting for 65 and $92 \%$ of adult value respectively, might be acceptable with limited risk of DOD whereas feeding level is high but balanced.

The CW gain and HW were correlated in a joint dependant manner to the occurrence of DOD. This suggests that a fast endochondral or intramembranous ossification process would be more critical than the mechanical effect of increased limb loading through weight increase in the causing of juvenile joint diseases. Furthermore, the present results suggest that large size would be a predisposing factor, whatever its origin (nutrition or genetic).

The determination of growth thresholds (especially for $\mathrm{HW}$ and $\mathrm{CW}$, and for BW to some extent) to individually optimise the level of nutrient intake of balanced diets fed to young horses might be an option to reduce the risk of DOD.

\section{ACKNOWLEDGEMENTS}

The authors acknowledge Dr A. Ellis and Pr P.R. van Weeren for their careful review of this article, and Pr J.M. Denoix, Dr S. Jacquet and Dr E. Cauvin for their generous contribution to the realisation and interpretation of X-ray studies.

The authors are grateful to the staff of the experimental farm of the French National Studs for their technical assistance.

This research was funded by the French National Studs (Haras Nationaux) and the Limousin Region.

\section{REFERENCES}

[1] Bigot G., Trilland-Geyl C., Jussiaux M., Martin-Rosset W., Élevage du cheval de selle du sevrage au débourrage : alimentation hivernale, croissance et développement, INRA Prod. Anim. 69 (1987) 45-53.

[2] Bridges C.H., Harris E.D., Experimentally induced cartilaginous fractures (osteochondritis dissecans) in foals fed low-copper diets, J. Am. Vet. Med. Assoc. 193 (1988) 215221.

[3] Cymbaluk N.F., Christison G.I., Leach D.H., Longitudinal growth analysis of horses following limited and ad libitum feeding, Equine Vet. J. 22 (1990) 198-204.

[4] Dik K.J., Enzerink E., van Weeren P.R., Radiographic development of osteochondral abnormalities, in the hock and stifle of Dutch Warmblood foals, from age 1 to 11 months, Equine Vet. J. Suppl. 31 (1999) 9-15.

[5] Doreau M., Boulot S., Martin-Rosset W., Robelin J., Relationship between nutrient intake, growth and body composition of the nursing foal, Reprod. Nutr. Dev. 26 (1986) 683-690.

[6] Doreau M., Dussap G., Estimation of milk production in the nursing mare by labeling the body water of the foal, Reprod. Nutr. Dev. 20 (1980) 1883-1892. 
[7] Doreau M., Martin-Rosset W., Dairy Animals: horse, in: Roguinsky H., Fuquay J.W., Fox P.F. (Eds.), Encyclopedia of Dairy Sciences, Elsevier, Amsterdam, The Netherlands, 2003, pp. 630-637.

[8] Dutra F., Carlsten J., Ekman S., Hind limb skeletal lesions in 12-month-old bulls of beef breeds, Zbl. Veterinarmed. A. 46 (1999) 489-508.

[9] Gee E.K., Firth E.C., Morel P.C., Fennessy P.F., Grace N.D., Mogg T.D., Articular/epiphyseal osteochondrosis in Thoroughbred foals at 5 months of age: influences of growth of the foal and prenatal copper supplementation of the dam, New Zeal. Vet. J. 53 (2005) 449-457.

[10] Glade M.J., Belling T.H., Growth plate cartilage metabolism, morphology and biochemical composition in over- and underfed horses, Growth 48 (1984) 473-482.

[11] Glade M.J., Reimers T.J., Effects of dietary energy supply on serum thyroxine, triiodothyronine and insulin concentrations in young horses, J. Endocrinol. 104 (1985) 9398.

[12] Henson F.M., Davies M.E., Jeffcott L.B., Equine dyschondroplasia (osteochondrosis)histological findings and type VI collagen localization, Vet. J. 154 (1997) 53-62.

[13] Hintz H.F., Hintz R.L., van Vleck L.D., Growth rate of thoroughbreds: effect of age of dam, year and month of birth, and sex of foal, J. Anim. Sci. 48 (1979) 480-487.

[14] Hurtig M.B., Pool R.R., Pathogenesis of equine osteochondrosis, in: McIlwraith C.W., Trotter G.W. (Eds.), Joint disease in the horse, Saunders, Philadelphia, USA, 1996, pp. 335-358.

[15] INRA, Alimentation des chevaux, INRA, Paris, 1990

[16] INRA-HN-IE, Notation de l'état corporel des chevaux de selle et de sport, Guide Pratique, Institut de l'élevage, Paris, 1997.

[17] Jeffcott L.B., Davies M.E., Copper status and skeletal development in horses: still a long way to go, Equine Vet. J. 30 (1998) 183-185.

[18] Jelan Z.A., Jeffcott L.B., Lundeheim N., Osborne M., Growth rates in Thoroughbred foals, Pferdeheilkunde 12 (1996) 291-295.

[19] Knight D.A., Weisbrode S.E., Schmall L.M., Reed S.M., Gabel A.A., Bramlage L.R., Tyznik W.I., The effects of copper supplementation on the prevalence of cartilage lesions in foals, Equine Vet. J. 22 (1990) 426432 .
[20] Kronfeld D.S., Meacham T.N., Donoghue S. Dietary aspects of developmental orthopedic disease in young horses, Vet. Clin. N. Am. Equine Pract. 6 (1990) 451-465.

[21] Martin-Rosset W., Vermorel M., Doreau M., Tisserand J.L., Andrieu J., The French horse feed evaluation systems and recommended allowances for energy and protein, Livest. Prod. Sci. 40 (1994) 37-56.

[22] McIlwraith C.W., Incidence of developmental joint problems, in: Mc Ilwraith C.W. (Ed.), Proceeding of AQHA Developmental orthopedic disease symposium, Amarillo, USA, 1986, pp. 15-20.

[23] Moore J.N., McIlwraith C.W., Osteochondrosis of the equine stifle, Vet. Rec. 100 (1977) 133-136.

[24] NRC, Nutrients requirements of horses, 5th revised ed., Subcommittee on Horse Nutrition Board, Agricultural National Academy Press, Washington, 1989.

[25] Olsson S.E., Reiland S., The nature of osteochondrosis in animals. Summary and conclusions with comparative aspects on osteochondritis dissecans in man, Acta Radiol. Suppl. 358 (1978) 299-306.

[26] Ott E.A., Brown M.P., Roberts G.D., Kivipelto J., Influence of starch intake on growth and skeletal development of weanling horses, J. Anim. Sci. 83 (2005) 10331043.

[27] Philipsson J., Pathogenesis of osteochondrosis - genetic implications, in: Mcllwraith C.W., Trotter G.W. (Eds.), Joint disease in the horse, Saunders company, Philadelphia, USA, 1996, pp. 359-361.

[28] Philipsson J., Andreasson E., Sandgren B., Dalin G., Carlsten J., Osteochondrosis in the tarsocrural joint and osteochondral fragments in the fetlock joints in Standardbred trotters. II. Heritability, Equine Vet. J. Suppl. 16 (1993) 38-41.

[29] Poulos P.W., Jr., Reiland S., Elwinger K., Olsson S.E., Skeletal lesions in the broiler, with special reference to dyschondroplasia (osteochondrosis). Pathology, frequency and clinical significance in two strains of birds on high and low energy feed, Acta Radiol. Suppl. 358 (1978) 229-275.

[30] Ralston S.L., Hyperglycaemia/hyperinsulinaemia after feeding a meal of grain to young horses with osteochondrosis dissecans (OCD), Pferdeheilkunde 12 (1996) 320-322.

[31] Reiland S., Morphology of osteochondrosis and sequelae in pigs, Acta Radiol. Suppl. 358 (1978) 45-90. 
[32] Richards J.R., A flexible growth function for empirical use, J. Exp. Biol. 10 (1959) 290 300.

[33] Robert C., Jacquet S., Valette J.P., Denoix J.M., Breed variations in the distribution of osteoarticular lesions in horses at weaning, in: van der Honing Y. (Ed.), Proceeding of the 56th Annual Meeting of the European Association for Animal Production, Uppsala, Sweden, 2005, p. 334.

[34] Savage C.J., McCarthy R.N., Jeffcott L.B., Effects of dietary energy and protein on induction of dyschondroplasia in foals, Equine Vet. J. Suppl. 16 (1993) 74-79.

[35] Savage C.J., McCarthy R.N., Jeffcott L.B., Effects of dietary phosphorus and calcium on induction of dyschondroplasia in foals, Equine Vet. J. Suppl. 16 (1993) 80-83.

[36] Trillaud-Geyl C., Brohier J., de Baynast L., Baudoin N., Rossier E., Lapierre O., Bilan de productivité sur 10 ans d'un troupeau de juments de selle conduites en plein air intégral. Croissance des produits de 0 à 6 mois, World Rev. Anim. Prod. 25 (1990) 65-70.

[37] van Soest P.J., Wine R.H., Use of detergents in the analysis of fibrous feeds. Determination of plant cell wall constituant, J. Ass. Agric. Chem. 50 (1967) 50-55.

[38] van Weeren P.R., Barneveld A., The effect of exercise on the distribution and manifestation of osteochondrotic lesions in the
Warmblood foal, Equine Vet. J. Suppl. 31 (1999) 16-25.

[39] van Weeren P.R., Sloet van Oldruitenborgh M.M., Barneveld A., The influence of birth weight, rate of weight gain and final achieved height and sex on the development of osteochondrotic lesions in a population of genetically predisposed Warmblood foals, Equine Vet. J. (Suppl. 31) (1999) 26-30.

[40] Vervuert I., Coenen M., Borchers A., Granel M., Winkelsett S., Christmann L., Distl O., Bruns E., Hertsch B., Growth rates and the incidence of osteochondrontic lesions in hanoverian warmblood foals, proceeding of the 18th Equine Nutrition and Physiology Symposium, East Lansing, USA, 2003, pp. 113-114.

[41] Watkins J.P., Osteochondrosis, in: Auer J.A. (Ed.), Equine Surgery, Saunders, Philadelphia, USA, 1992.

[42] Whitton R.C., Equine developmental osteochondral lesions: the role of biomechanics, Vet. J. 156 (1998) 167-168.

[43] Winsor C.P., The Gompertz curve as a growth curve, Proc. Natl Acad. Sci. USA 18 (1932) 1-18.

[44] Wu F.M., Hedhammar A., Krook L., Overnutrition and skeletal disease. An experimental study in growing Great Dane dogs. IX. The long bones, Cornell Vet. 64 (1974) (Suppl. 5) 83-114.

To access this journal online: www.edpsciences.org 